\title{
The Political Use of the Teshuva Cassette Culture in Israel
}

\author{
Nissim Leon
}

Received: 24 March 2010/Accepted: 10 June 2011/Published online: 1 July 2011

(C) The Author(s) 2011. This article is published with open access at Springerlink.com

\begin{abstract}
The present work of ethnography describes the political uses of audiotapes and videotapes by religious fundamentalists in Israel during the 1990s. The article deals with the use of the teshuva cassette culture in constructing Shas's political message in the 1999 Knesset elections. Shas presented the videoand audiotape "J'Accuse" as a way of contending with the crisis of confidence that resulted from the criminal conviction of its political leader. But the content of the cassette was not the only message. The cassette replicated the way the teshuvamovement tapes undermined and criticized the mainstream media discourse during the 1990s in Israel. In fact the cassette itself was the message. And this message should be studied in relation to the way the teshuva movement designed the cassette culture as a source of religious truth as well as political truth being concealed from the public.
\end{abstract}

Keywords Teshuva movement $\cdot$ Cassette culture $\cdot$ Shas $\cdot$ Aryeh Deri

\section{Introduction}

Research on the audio- and videocassette culture of the Israeli teshuva movement has so far discussed the cassettes as a means of spreading religious messages and strengthening the haredi enclave. ${ }^{1}$ Less attention has been paid to the political use of the teshuva movement cassettes, whether as a relatively inexpensive way of disseminating messages or as a means of delineating an alternative sphere for

\footnotetext{
1 The term "teshuva movement" is synonymous in the jargon of Israeli religious society with a spectrum of organizations and initiatives engaged in persuading individuals and collectives to view the haredi way of life as the proper standard for religious and community life.
}

N. Leon $(\bowtie)$

The Sociology and Anthropology Department, Bar-Ilan University, Ramat-Gan, Israel e-mail: nissimnu@bezeqint.net 
political discourse instead of the state. A salient example of such political use, which I address in this paper, is the case of an audio- and videocassette produced by the Mizrahi-haredi party Shas to contend with a potential political crisis following the conviction of its charismatic political leader, Aryeh Deri, on criminal charges shortly before the 1999 Knesset elections. On a campaign cassette, whose title"J'accuse!" - conveyed an emotionally charged historical message, Deri appealed personally to the Israeli people with his version of the events for which he had been convicted.

Analyses of the rhetorical and symbolic content of the tape have been used by scholars of Shas and Mizrahi haredism in discussing the ethnic and haredi narrative of the party and the circles it represents (Bilsky 2001; Hazan 2000). But one topic that has been left out of the scholarly discussion is the medium itself: the cassette. One might think there was nothing of interest here. Functionally, the use of cassettes is understandable: they were a quick, inexpensive, efficient means of conveying Deri's claim of innocence, in his own voice, to as much of the country as possible. But in addition, the "J'accuse!" tape was a cultural item belonging to the counterpublic of the Mizrahi haredi teshuva movement in Israel. Years of exposure to the "cassette culture" of the teshuva movement had instilled in Shas circles the belief that cassettes revealed the truth that the establishment was hiding from the public. The "J'accuse!" cassette was designed and distributed in a form resembling teshuva movement cassettes. The content was not the only message. The tape itself was the message.

My argument will be based on ethnographic findings from years of fieldwork among Mizrahi haredim in Israel. The fieldwork, carried out from 1999 to 2003, included observing preachers in the haredi teshuva movement, interviewing leading Shas activists, and keeping track of the campaign methods used by Shas in the 1999 elections. It also included witnessing directly the way the "J'accuse!" cassette was distributed and received among potential Shas voters in Sephardi congregations.

The paper is divided into three sections. The first section describes the background of Shas and recounts the trial of its charismatic political leader, Aryeh Deri, in the 1990s, and the party's reaction to the verdict. The second section discusses the connection between Shas and the teshuva movement and also sheds light on the culture of that movement. The third section expands on the use that Shas made of the teshuva movement's "cassette culture" in order to persuade its constituents that its leader was innocent, despite the court's guilty verdict.

\section{Shas, the Deri Trial, and the "J'accuse!" Campaign Cassette}

Shas was founded in 1984 as a political home for Mizrahi bnei Torah (haredi yeshiva students and alumni) who felt discriminated against in the Ashkenazi-led haredi society. It adopted the organizational patterns of the veteran Ashkenazi haredi party Agudath Israel, including the division between spiritual and political leadership; the former set the agenda while the latter advise and carry out the decisions of the former. As in Agudath Israel, the bnei Torah recognize the leadership hierarchy and accept the decisions of the spiritual leadership. 
Shas's political leader in the 1990s, Aryeh Deri, was born in Meknes, Morocco, in 1959, and moved to Israel with his family in 1968. He received a haredi education in yeshivas such as Porat Yosef and Hebron (Knesset Yisrael). His close relationship with the family of Rabbi Ovadia Yossef when he was a young married student, combined with his talent as a political advisor, stood him in good stead and he obtained a high-level position in Shas. Despite his youth, he was appointed director general of the Interior Ministry. When he was named Minister of the Interior in 1988, Deri became the youngest government minister in Israeli history (Dayan 1999, pp. 58-84; Nir 1999).

Deri turned Shas into a leading player in Israeli politics. He was prominent in implementing the party's political strategy, which included openness to the media, growing involvement in state affairs, and coalitions with parties on the left and right. In addition, Shas established schools, radio stations, and local welfare services that helped it tremendously in building support among voters. These factors together led to electoral success and helped Shas become a crucial factor in political coalition-making in the 1990s. The party began to play an active role in governance, while demonstrating responsibility for society as a whole and seeking to overcome the sectoral image of haredi society. Unlike Agudath Israel, Shas had no objection to asking for major ministerial positions and appointments of national significance, such as the position of deputy prime minister, which it demanded in the late 1990s (Alush and Elituv 2004, p. 331). This was extroverted, self-confident haredi politics, capable of making demands and overt threats. But Deri's charismatic leadership of the party and its cultural environment was marred during the 1990 s by a dark shadow: the "Deri trial."

In June 1993, Interior Minister Aryeh Deri was charged with bribe-taking and breach of trust. He was suspected of accepting \$150,000 from haredi businessmen to buy apartments in Jerusalem. He was also suspected of illegal transfers of money from the Interior Ministry to institutions associated with his party. The Deri trial went on throughout the years of Shas's electoral expansion and its consolidation as a significant organization in Israeli politics. The party's spiritual and political leaders assured Israelis that Deri would be acquitted and that the libelous nature of the charges would become clear in court. But in March 1999, about 3 months before the Knesset elections (which had been moved up due to a parliamentary crisis), Shas found itself facing tough questions due to the conviction of its leader. The event seemed so significant in the Israeli political climate at the time that the court session at which the verdict was handed down was broadcast live on state radio and television.

The verdict, according to journalists who were following Shas leaders up close, elicited a sense of severe crisis among the party leadership (Alush and Elituv 2004, pp. 332-335). First of all, Deri's political career had apparently ground to a halt, terminating the growth of the party that had become so closely identified with him. None of the leading party figures seemed capable of stepping into Deri's shoes. Shas activists were frantic. "Deri is our leader," one local party activist in Petah Tikva told me at the time. "Without him the party cannot be picked up." "I feel like an orphan," an activist from Holon told me, adding, "I'm in despair. Where do we begin?" Overnight Shas had become a party without a political leader and was 
consequently doomed to fail in the upcoming elections in May 1999. "Failure," as I learned from my fieldwork at the time, was interpreted by people in the party as the inability to maintain the party's strength and even to increase it. Years of work in education, public relations, and the founding of institutions seemed to have been for naught. In terms of political legitimacy as well, Shas found itself with a major image problem. The headlines in the major newspapers, articles by pundits, and the public discussion left no doubt: Shas was seen as a deeply corrupt party that cared only for its leaders, activists, and rabbis and not at all for the Mizrahim in the periphery. The press also made sure to remind people of other criminal cases involving Shas figures in the 1990s. For example, MK Yair Levy had been convicted of embezzlement and forgery and spent three years in jail. "Everyone was against us," Yehuda Avidan, a leading figure in Shas, told me after the elections. "This trial seemed to us like an electoral attack. Clearly, something had to be done fast."

Deri and Shas chose to contend with the verdict by producing a campaign cassette entitled "J'accuse!" In every election campaign since 1988, Shas had produced a cassette with campaign songs and a call by its leaders to vote for Shas. But this tape was different. It was entirely about the Deri trial and Deri's response to what the judges had said in support of their verdict. The cassette was produced in two versions-video and audio. The more widespread one was the videotape, designed for non-haredim, i.e., those who had a television set at home. The cassette was an integral part of Shas's election campaign. As I saw with my own eyes, party branches, synagogues, batei midrash, and yeshivas associated with Shas did all they could to distribute it among regular and potential supporters of the party. From some of the distributors, who included kollel students and young yeshiva students, I learned that the tape was a weapon in the fight for the public trust and in an attempt to turn Deri into a religious-political martyr whose unending persecution by the establishment deserved to be put on trial in the public court of justice, i.e., the elections.

In the 1999 Shas election campaign, there was a clear division of labor between the official campaign commercials and the campaign on the ground (see also Alush and Elituv 2004, p. 334). The commercials were limited in time and subject by law to the direct, daily oversight of a Supreme Court justice. Therefore, aside from occasional passing references to the claim that Deri had been wronged, they focused on the party's traditional messages: the attempt by its rabbis to restore the lost glory of Jewish religious tradition and to faithfully represent the Mizrahi version of that tradition. In contrast, the campaign on the ground focused mainly on the Deri trial. Anyone walking through the Carmel market in Tel Aviv, one of the main open-air markets in Israel in April or May 1999 could see the magnitude of the success that Shas could expect. The market had been known in the past as a stronghold of the Likud party. But in 1999 the story was completely different. Instead of Likud posters and pictures of the Likud prime minister, Binyamin Netanyahu, almost every stall had a poster of Deri. One of the favorites showed Rabbi Ovadia Yossef gazing sadly at Deri; at the bottom were the words, "A Torah scroll is suffering." In addition, the "J'accuse!" cassettes were available-for free, of course-at some of the stalls where the vendors looked like traditionalist Mizrahim, not haredim. 
In interviews that I conducted about a year after the elections, Shas activists described the distribution of the cassette in thousands of copies as a fire in a field of thorns. "With another 2 weeks," Yehuda Avidan told me, "we would have brought in the twentieth seat, too." "The cassettes ran out," David Hakham, a broadcaster for a pirate radio station associated with Shas circles, told me. "I was constantly talking to the party to get more cassettes, but they couldn't keep up. It really felt like an earthquake." There is no definite, quantitative evidence to support these feelings. But my impression was that at least in the places where I did my fieldworkMizrahi synagogues in central Israel and the periphery that had a salient core group of newly observant Jews-there was great interest in the cassettes. Several synagogues had a specific spot where the cassettes were always placed. From time to time a worshipper or local Shas activist would come and replenish the stocks. Spending time among these congregations led me several times to the homes of worshippers' families. Thus, on several occasions, I was able to see with my own eyes families or groups of Mizrahim, both secular and traditionalist, watching the video, discussing it, arguing about it, and often identifying with its messages. What stood out was the pattern of viewing. The video was watched not by individuals but by groups that got together specially for this purpose. For example, around the snack-covered table of a traditionalist Mizrahi family in Yad Eliyahu, Tel Aviv, I watched the video again. What stood out in my mind, based on conversations with the people there, was that these tapes were believed to expose what was being hidden from the public eye. In the words of a young woman from Bat Yam who described herself to me as not haredi but having no objection to her brothers' increasing religious observance:

It used to be that people from where my parents came from couldn't read Hebrew so well, so it was always possible to dupe them. Also there was just the [broadcast] news, and Haim Yavin [the TV news anchorman] was God. But now there are cassettes. People hear, people aren't blind, they see what Channel 1 and Channel 2 ...-all the left-wing media-are trying to hide. But we're always seeing on television and reading about how everything in this country is corrupt. Even the court is corrupt. What don't we know? Listen to Rabbi Amnon Yitzhak. He explains these things best. I don't have the energy.

This assertion, though ostensibly self-contradictory, was repeated with variations elsewhere. The tape was perceived as part of a political awakening. "It opened my eyes," a vendor in the Carmel market told me. "Last time I voted for the Likud," said a worker in a Holon garage who was a regular at the Ateret Hakhamim synagogue. "Now I'm convinced. It's an injustice. Only Shas! Write this down: Only Shas!"

\section{Shas and the Teshuva Movement Cassette Culture}

Shas's power base came together in the 1990s around a diverse core of voters as a reaction to the Ashkenazi haredi parties. Its core consists of haredi bnei Torah and 
newly haredi Jews. In addition, there are semi-secular voters, referred to in Israeli sociology as "traditionalists" (Yuchtman-Yaar and Hermann 2000).

From the time of its inception, Shas managed to convert social and political conditions into efficient action strategies that suited the predispositions of the Mizrahim who formed its target population. Strong tradition and faith (Deshen 2005), issues of ethnic and national identity against a backdrop of economic globalization and secular-civil ideology (Peled 2001), ongoing discrimination and ethno-class disparities (Picard 2007), an electoral system well suited to small and medium-sized parties (Tesler 2003), religious activism, and emphasis on education (Feldman 2001) all helped Shas grow into a powerful party in Israeli politics. As early as 1984, Shas surprised the country by winning four Knesset seats. The party then recorded a dramatic rise in its power in the 1996 elections, receiving ten seats. The teshuva movement helped it to accomplish this, both by articulating the Mizrahi-haredi message and by creating the means of spreading this message in everyday life between elections (Lehmann and Siebzehner 2006). But the conviction of Aryeh Deri looked as though it would put an end to Shas's success. Not only would the party be unable to maintain its achievements, but it was at a turning point that could lead to a decline in its strength. For the first time it seemed that Shas would be facing a major crisis of confidence among its supporters.

Shas's ability to forge a connection between haredi ideology and non-haredim rests on the essential, instrumental relationship that it developed with the haredi teshuva movement, a relationship that has at times led to the description of Shas as a "church party" (Fischer and Bekerman 2001). This relationship has three aspects that can be found in the party's organizational, conceptual, and campaign environment:

1. Responsibility: Shas considers itself responsible for the organizations and initiatives that make up the haredi teshuva movement. This sense of responsibility is manifested in the channeling of state budgets to organizations that encourage Jews to become observant and in the building of educational institutions for newly religious Mizrahim (Tesler 2003, pp. 167-175; Ilan 2001, pp. 153-168).

2. Leadership: The spiritual leadership of Shas consists of heads of established yeshivas and prominent rabbis of towns or neighborhoods. But with respect to political leadership, things have changed over the years. Whereas in the second half of the 1980s, the party's political representatives came mainly from the yeshivas and the formal rabbinical elite, by the mid-1990s they were being chosen primarily from among teshuva-movement workers. A salient example is Shlomo Benizri, who became religious as a young man and later served as the mashgiah ruhani (a sort of spiritual counselor) at the Or Hachaim yeshiva for the newly observant in Jerusalem. Another example is Yitzhak Vaknin, one of the leading supporters of teshuva movement preacher Amnon Yitzhak.

3. Media: Many of the teshuva movement's political messages are expressed in Shas's campaigns, from the slogan calling for the restoration of the lost glory of Jewish religious tradition to the use of the term teshuva to establish a connection between the haredi leadership and traditionalist population groups 
(Fischer and Bekerman 2001). Three technological media used by the teshuva movement have become integral parts of Shas's media activity as well: rallies (Leon 2003), pirate radio stations (Limor and Naveh 2007), and audio- and videocassettes (Amran 2006). The "J'accuse!" tape belonged to the last category.

The term "cassette culture" originally referred to a revolution in popular music from the mid-1970s through the 1980s. Because audio- and videocassettes were inexpensive and easy to distribute, they could be used to develop an alternative musical space alongside the hegemonic musical cultures of the state or the mainstream market (Abu-Lughod 1989; Manuel 1993; Miller 2007).

Eventually, the cassette culture, especially among Muslims and haredi Jews (Hirschkind 2006; Caplan 2007), was adopted by conservative religious movements and fundamentalist movements to disseminate their critical religious, cultural, and moral messages en masse. A salient example of the political effects of the cassette culture could be seen in Iran before the clerical revolution. Audiocassettes were an important propaganda device used to prepare public opinion for the 1979 revolution, deepen distrust of the government, and provide incentive for turning this distrust into political practices that would lead to a change in government. The cassettes also served to form a political and social bond among listeners (Sreberny-Mohammadi 1990). The cassette culture helped create a sense of community that could overcome geographical distance and the political difficulty of conveying the message (Sivan 2005; Furman 1997; Kramer 1997). It also delineated alternative expressive spaces that took the form of what Michael Warner has termed "counterpublics," i.e., spaces for reflexive discourse in contrast to the official, established discourse of collectives organized around the state and its institutions (Warner 2002).

In Israel the term "cassette culture" is associated with Mizrahi music-ethnic music with a sound that resembles Turkish, Greek, or Arab music, sung and played mainly by musicians of Mizrahi origin. Since the mid-1970s, the terms "cassette singer" and "cassette music" have been synonymous in Israel with the Mizrahi genre. Audiocassettes helped the stars of the Mizrahi genre to circumvent the regime of the dominant taste led by agents of the national culture in the mainstream media. The cassettes, sold for relatively low prices, helped to bring Mizrahi songs to large audiences, and served as a sort of alternative auditory space to mainstream Israeli music (Perlson 2006; Regev 1996). But in the 1980s and 1990s, cassettes were also an integral part of another alternative auditory space-dissemination of the haredi religious message among non-haredi Mizrahi traditionalists (Goodman 2002; El-Or 2006, pp. 162-183). This process is identified with the activity of the teshuva movement.

Teshuva movement cassettes are mostly recordings of sermons or lectures delivered at synagogues, reception halls, and other mass venues. In the 1980s and 1990s, teshuva movement preachers tended to use their recorded lectures to convince Mizrahim to change their identity and become haredi, or at least to recognize the authority of the haredi rabbis. The language of the preachers on the teshuva movement tapes was sensitive to the social environment of the Mizrahim who comprised their main target audience. The content corresponded with the 
linguistic, social, and economic landscape of the daily lives of Mizrahim in Israel. Some of the content of the sermons, including ideas and figures of speech, have become part of the religious and community language. This contributed to a distinction between listeners and those outside their social world (El-Or 2006).

In the 1990s, the teshuva tapes could be obtained at rallies led by teshuva movement preachers, in synagogues, and in yeshivas for the newly observant. Special tape libraries were even established (Amran 2006), where people could obtain the cassettes for a nominal price or simply by promising to return them. Sometimes the cassettes were distributed at road junctions and in public places; the idea was to give "spiritual merit" to the people by sharing the religious message on the tapes with them (Leon 2008). When tapes were sold, the price was usually very low. The tapes were well suited to the relatively poor material conditions in disadvantaged urban neighborhoods and development towns in the geographic periphery where many Mizrahim live. Teshuva movement preachers such as the brothers Yossi and Nissim Yagen and Rabbis Reuven Elbaz, Amnon Yitzhak, Daniel Zar, Haim Rabi, and Yosef Mugrabi became household names in the 1990s among religiously observant and traditionalist Mizrahim. They came to be associated with religious and social changes that occurred among Mizrahi Jewry under the influence of haredi trends. People influenced by the teshuva movement came to perceive them as being equal in stature to the leading halakhic authorities (Goodman and Bilu 2004). Eventually, some of these preachers-including Reuven Elbaz and Daniel Zar-even became rabbis of communities. Pictures of well-known teshuva movement preachers can be found hanging in homes and businesses next to those of renowned halakhic authorities and kabbalists, whether as an indication of faith in their magical powers or as a sign of adherence to the educational principle "Let your eyes see your teachers." In recent years some of the tapes of leading teshuva movement preachers have even been transcribed and published as books on faith and religious instruction (e.g., Yagen 2008; Arush 2006). Unlike the audiocassettes, the written versions have no direct political message; they are simply a means of steering people towards the haredi way of life.

Preachers on teshuva movement cassettes in the 1980s and 1990s focused mainly on persuading diverse groups of Israeli Mizrahim to become religiously observant or to strengthen the religious foundations of their lives. The main message communicated on these tapes was a call to strengthen one's faith in God and recognize the superiority of the haredi ideology (Blondheim and Caplan 1993). But these preachers were not just conveying messages of belief. They were also conveying messages of unbelief. These latter messages mainly involved criticism of the Israeli establishment, especially the education system, media, judicial system, and administration. Israeli history and mythology also came under the rod of criticism. The tapes attempted not just to teach listeners Torah and haredi faith but also to give them critical tools for dealing with the world around them. For example, they taught that behind every newspaper article, behind every judicial commotion, behind every scholarly paper hides a political agenda. In other words, these are not objective texts but biased ones, for the most part intended to serve the enemies of truth, i.e., the enemies of religion. The cassettes also taught listeners that this 
"truth" can be discovered by listening to its voice resounding from one place- - the cassette.

To clarify the argument, let us look at the case of Rabbi Amnon Yitzhak, one of the leading teshuva movement preachers active among Israeli Mizrahim, and one of the main developers of the teshuva movement cassette culture in Israel and abroad (Givon 2003; Sharabi 2004; Goodman 2002). An examination of the many audioand videotapes that he produced in the 1990s shows that along with urging listeners to become religiously observant, he encouraged reflection and critical thinking regarding the circumstances surrounding observant Jews in Israel. Thus, over time, Amnon Yitzhak's teshuva drama became a political drama. The teshuva show bore not only a religious message but also sharp criticism of Israeli society and politics. One of the main topics addressed by Yitzhak throughout the 1990s was the media. He educated his listeners to see the established media as liars. One means of doing so involved counter-investigations, which he carried out in the 1990s in response to investigative reports on him or his assertions. Entire cassettes by Amnon Yitzhak were devoted to refuting these reports-which tended to portray him as a controversial, manipulative cynic-either by pointing out what he considered logical contradictions in the investigative reports or by presenting other facts that contradicted the findings of the investigations or the allegations against him. Thus, over time, Amnon Yitzhak's audio- and videocassettes became some of the most powerful expressions of the counterpublic of the teshuva movement.

This method of propaganda, with its means and logic, would be one of the main inspirations for Shas in contending with the conviction of Aryeh Deri.

\section{"J'accuse!"-The Cassette is the Message}

The "J'accuse!" cassette spearheaded Shas's efforts to turn the 1999 election campaign into a vote of confidence in Deri's leadership and his version of the story, and indirectly into a vote of no-confidence in the Israeli justice system. On one level was the content of the direct arguments designed to persuade people of the version being disseminated by Deri and Shas. On the other level was the wrapping of the content in the teshuva movement culture, where the cassette itself is the message.

The "J'accuse!" cassette presents Deri's version of the allegations. In addition to the evidential matter-which is structured, like Amnon Yitzhak's cassettes, as a sort of counter-investigation of the indictment-the ethno-religious interpretation of the conviction stands out through its linkage of the allegation of anti-Mizrahi discrimination in Israel and secularist attempts to harass haredim with the idea of ongoing persecution of the Jews by their enemies. The cassette contains brief interviews with rabbis, public figures, and people in the justice system, religious and secular alike, praising Deri and disagreeing with the court. Deri is depicted as a simple Jew working on behalf of the community who loves other people and is loved by them. He is portrayed as a man being harassed by the Israeli justice system-an exclusive club of the old elites-because of his haredi and ethnic identity and his success in helping the Mizrahim and haredim improve their circumstances. 
The "J'accuse!" video uses three main lines of argument that can be termed "the hierarchy," "the absurd," and "the comparison." It begins with Judge Yaacov Zemach, a religiously observant Mizrahi Jew, saying that the court has decided to convict Aryeh Deri. The camera then immediately moves to the across-the-board agreement by the spiritual leadership of Shas with the assertion by the party's spiritual leader, Rabbi Ovadia Yossef, that Deri is innocent. The hierarchy is clear: the Supreme Court can say what it wants, but the spiritual leadership, which is the court of the Torah, i.e., the true Supreme Court, says otherwise. The claim of the absurd is manifested in the way the preparations for the trial are presented. The video focuses on the police preparations for the verdict. Hundreds of armed police officers are shown preparing for the court session at which the verdict would be handed down. Deri, the video tacitly claims, was portrayed by the state as a dangerous criminal and perhaps even a terrorist. It is as though the editors of the video were trying to call into question the state's scale of priorities and thus also its logic. Is Deri really another Adolf Eichmann or Ivan Demjanjuk? Can Israel really afford to spend time and resources on the ostensibly minor story of Deri, while major terrorist attacks are being perpetrated? The rhetorical answer, no, is supposed to lead viewers to the conclusion that it was not Deri on trial here but what he represented-the Mizrahi haredi revolution that the old-time Ashkenazi elite was trying to stop. From here the video moves on to a comparison between Deri's living conditions and those of the people who tried him. The deluxe homes of the judicial elite, who are portrayed as being cut off from the people, are contrasted with the accentuated poverty in Deri's own home; it is pointed out that Deri, who was accused of being greedy, in fact spent days and nights working on behalf of society, sometimes even spending his own money for it. Afterwards we see an Israeli flag on which the Star of David is replaced by the word "Shas." The video ends with a paean of praise to Deri, composed by singer Benny Elbaz (who himself became observant as an adult), its lyrics echoing Rabbi Ovadia Yossef's televised public statement immediately after the trial: He is innocent!

In terms of the content, we can say that the tape was, as Bilsky (2001) suggests, part of a "contest of narratives" - a competition between the narrative of the rule of law and the Mizrahi-haredi narrative of Shas circles. The former tried to present the Deri affair as the story of the struggle of the rule of law against the cancer of governmental corruption that had metastasized into the office of the Interior Minister. The Mizrahi-haredi narrative of Shas circles painted a different picture. The "J'accuse!" cassette portrays the Deri story not just as one more case in the history of relations between the justice system and politics in democratic Israel, or in the history of Mizrahi ethnic parties in Israel. The title of the cassette and the media coverage of the trial link the case plainly with the Dreyfus trial-a trial synonymous in Western culture with an evil plot driven by xenophobia. Dreyfus, a French-Jewish officer, was charged in 1895 with espionage. After being convicted, he was demoted in a humiliating public ceremony and sent to prison. The case received extensive publicity. The title of the cassette-“J'accuse!"-is an allusion to an article by author Emile Zola, who had the courage, about 3 years after the trial, to come out against public opinion and the opinion of the French elite and protest the injustice he believed had been done to Dreyfus in view of the accumulation of 
evidence indicating his innocence. Deri, the audiences of the "J'accuse!" tape were told, was the Israeli Dreyfus: a member of a minority group, both haredi and Mizrahi, a definite "other" to the dominant Israeli culture (El-Or 2006, pp. 90-91), who had managed to reach the peaks of power in Israel and found himself persecuted for his political and personal success due to his ethnic and religious identity. Like Dreyfus, he had been subjected to a public humiliation ceremony (Yadger 2003) and publicly stripped of the signs of his office and leadership. But because no one had the public courage to defend him, he was being forced to defend his innocence himself. It was as though the messages of the tape momentarily forged a link between the radical Mizrahi outlook and the radical haredi outlook, between the portrayal of Deri as an Israeli Black Panther representing the Mizrahi struggle in Israel and the portrayal of him as a haredi Jew exiled among Jews and persecuted for his desire to spread his faith. ${ }^{2}$ The "J'accuse!" cassette sought to change Deri's image from the epitome of a corrupt person representing a corrupt system to someone paying the price for the success of haredim and Mizrahim in penetrating the new elites.

It is worth noting another two haredi narratives evoked by the choice of the Dreyfus story and the use of a phrase-“J'accuse!"-that operates on the contemporary Jewish historical consciousness. First of all, the story that Shas chose to allude to is a cornerstone of the Zionist narrative. The Dreyfus trial is often described as the moment Herzl realized that there could be no solution to the problem of the Jews on European soil. This time Deri seemed to be using the Dreyfus trial to awaken his voters from the illusion of their acceptance by Israeli society and to urge them to organize. Second, the phrase "J'accuse!" is notable given that - as scholars of fundamentalist movements, and especially evangelistic movements, are aware-financial and sexual scandals have often led to public dramas of confession, remorse, and rebirth (Harding 2000, pp. 247-269). But in Deri's case we find the opposite — not a Jewish-style confession ("We have sinned, we have betrayed, we have stolen") in accordance with the Jewish principle that "one who confesses and abandons [the deed] will be treated with mercy," but "J'accuse!" Incidentally, on several occasions Deri himself, when addressing his loyal followers, referred to the trial in terms of a necessary "rectification" of his soul. But this "rectification" was not just personal but collective. Deri portrayed himself as a sacrifice offered by the public in the name of the religious revolution that it was attempting to carry out. On the cassette, i.e., in his appeal to the general public, we see him not asking forgiveness but, on the contrary, pointing an accusing finger at the law enforcement systems.

In terms of content, we have to turn our attention to the performative level, too, and look at political media activity by the counterpublics of the cassette culture. In the 1999 election campaign, Shas took a page out of the book of the teshuva

\footnotetext{
${ }^{2}$ The Black Panthers were a Mizrahi protest movement active in the early 1970s in disadvantaged urban neighborhoods and the periphery. Its members led numerous demonstrations against the Israeli government, which they accused of neglecting and discriminating against Mizrahim. This movement, like other Mizrahi political movements, was swallowed up in the political party system after the Yom Kippur War and died out. However, the term "Black Panther" remains part of the collective memory of radical protest against ethnic inequality.
} 
movement preachers. Deri's tape is clearly a campaign cassette. People familiar with the electioneering methods used until then no doubt recognized the attempt to "sell" them messages. Nevertheless, for the first time they were given a direct visual document, one that they could watch again and again, pass on to friends, and think about. Furthermore, the style of the cassette was reminiscent of the style used by teshuva movement preachers, and this fact was apparently of some significance in the 1999 elections. For instance, the cassette took its title from an expression familiar from Jewish culture and history. This is common in Amnon Yitzhak's teshuva tapes. "Queen of the Bathtub"-produced by him in the 1990s_takes its title from an influential Israeli play of the 1970s. Similarly, the title of the cassette "A Fact in the Eyes" is a play on words that corresponds with the media text of a popular Israeli investigative television program in the late 1990s-Uvda (literally, "fact").

The "J'accuse!" cassette also helped Shas link the Deri affair with the distrust familiar from the radical repertoire of the teshuva movement culture. Like the investigative programs and newspaper exposés that occupied more and more of print journalism and television in the 1990s, teshuva movement audiocassettes were an arena where events were taken apart and reassembled. In the 1990s, teshuva movement activists managed to give the tapes a reputation for being the equivalent of trustworthy investigative programs. When voters who were unsure whether to vote for Shas saw the "J'accuse!" video, which resembled videos distributed by teshuva movement preachers, what they saw was not Aryeh Deri's version of the events, but the results of a counter-investigation that the mainstream media had supposedly concealed from them. Aryeh Deri and Shas knew this. They were not just using the people in the teshuva movement to broaden Shas's strength; they were also using the culture of the teshuva movement, or more precisely, the radical structuring of its "objective" and "apolitical" perspective on reality, to persuade voters, haredim and traditionalists alike, not to abandon Shas and even to help it grow in view of the supposed miscarriage of justice that had been revealed-on tape as usual-before their very eyes. The medium of teshuva cassettes thus became the interpretive framework through which voters contended with the allegations against Deri.

\section{Conclusion}

The ethnographic work of Hirschkind (2006) on the cassette culture in contemporary Egypt demonstrates the political role of the cassettes in the development of a counterpublic. Hirschkind describes how the cassette culture functions as a source of complementary or subversive interpretations vis-à-vis the government. The cassettes are comparable to journalistic commentary that uses inexpensive means to forge citizens' reflective and critical view of the situation around them. Although some people might say that Israeli and Egyptian democracy are worlds apart, in both societies the religious cassette culture not only calls for a return to religious tradition and the development of a counterculture, but also conveys a political message, claiming to be an authoritative alternative to the government and in possession of 
political truth that is being hidden from the people. Shas's use of the "J'accuse!" cassette in 1999 shows that this political message is not manifested solely in the content of the cassette; it is conveyed by the packaging and form of the cassette, whether an audiocassette or a videocassette and by using images taken from the critical discourse of the teshuva cassette culture.

We have seen that Shas used the audio- and videocassette "J'accuse!" to contend with the possibility of a crisis of confidence among voters following the conviction. The content of the cassette was not the only message in the contest of narratives between Shas circles and the judicial and media establishment. To paraphrase McLuhan (1964), in this case the cassette was the message. And this message should be studied in relation to the programmatic and performative place occupied by the political discourse of the teshuva movement in the Shas campaign. The "J'accuse!" tape was presented as another link in the chain of teshuva movement cassettes, making it easier to accept its messages, which were ostensibly faithful to a political truth that had been concealed from the public and had been exposed democratically in the alternative auditory space of the cassette culture. Shas was thus able to temporarily shake off its image as a corrupt religious party within the Israeli establishment and to present itself as a subversive, radical, and reactionary political organization being persecuted for its principles.

It is not clear whether the "J'accuse!" cassette was worth the effort. As I mentioned above, we have no way of measuring its electoral impact. What is clear is that the cassette was used prominently in the Shas campaign and that large numbers of potential Shas voters saw or heard it. The cassette was one of several factors involved in Shas's electoral growth throughout the 1990s- the two-vote system, the use of folk-religion messages, the charisma of the spiritual leadership, the image of Shas as a socially concerned party that takes care of weak population groups in view of widening socio-economic disparities and preserves the Jewish identity of the State of Israel (Caplan 2008). What is also clear is that Shas won seventeen Knesset seats in the 1999 elections; i.e., it put seventeen haredi representatives in the Knesset in addition to the five or six fairly constant seats received by the Ashkenazi haredi party United Torah Judaism. Shas not only became the third-largest party in the Knesset but was just two seats behind the former ruling party. At the time, before such scenes became routine in Israeli politics, this achievement seemed so dramatic that it somewhat overshadowed the third political reversal in Israeli history, led by the head of the One Israel party, Ehud Barak. The crowds that filled Rabin Square in Tel Aviv and listened to Barak's victory speech shouted from time to time, "Just not Shas! Just not Shas!" "Shasophobia," Ha'aretz journalist Neri Livneh would term it-fear of the enigmatic, growing, and apparently inexhaustible power of Shas.

By May 1999, it was clear that Shas was not a passing sectoral political episode. It had the potential to become a genuine alternative force with a message for all Israelis and had no qualms about using Israeli democratic culture to promote a fundamentalist religious agenda in competition with the existing agenda. But Shas, which since its inception in 1984 had grown into a solidly established party with educational, welfare, and social-services systems and access to government resources, faced the possibility of being excluded from the coalition and unable 
to protect its assets from up close and perhaps even to expand them (Cohen 2001). The party's spiritual leader, Rabbi Ovadia Yossef, seems to have been aware of the power trap that Shas was in; apparently he was also aware of Deri's charisma and the possibility that some thought of him as the true leader of Shas. Within less than a year, Aryeh Deri was replaced by Eli Yishai, a leading Shas figure and a former assistant to Deri. Though less charismatic than Deri, Yishai was loyal to Rabbi Ovadia Yossef and shared his belief that Shas had to be able to tip the balance and not serve as an opposition force trying to take over the government. The "J'accuse!" cassette was shelved. Deri was given a 3-year sentence, which he served in the Ma'asiyahu prison, and his involvement in Shas political activity declined.

For several years after being released from jail, Deri was legally prohibited from holding public office. This has made it very difficult for him to return to politics in a significant way. Ever since the restriction expired, some people have believed Deri was back on track to resume the political leadership of Shas. In fact, things have turned out to be more complex. Shas has not welcomed its former leader back with open arms. Deri is considered a potential threat to the balance of political power that developed in Shas after his departure and to the party's image. Over the years, his place has been taken by political leaders who turned Shas from an ethnic party with a haredi leadership into a haredi party with an ethnic leadership. Unlike in the Deri era, the political leadership has confirmed the standard division in haredi parties between the spiritual leadership, which makes the decisions, and the political leadership, which is merely advisory. The new leadership has also tried to cleanse itself of all hints of corruption; its support for leaders who have been deemed dishonest is purely symbolic. Deri has also found that the "spiritual revolution" that Shas tried to accomplish under his leadership, which reflected the active efforts of the teshuva movement to expand its ranks, has been replaced in the past decade by a desire to preserve the party's achievements as much as possible and to maintain the political status of the haredi scholarly society in Israel. It is not clear what will happen when Rabbi Ovadia Yossef is no longer around. What is clear is that the Shas that considered itself the leader of an active religious revolution is no more.

In general, one could argue that Shas's exploitation of the teshuva movement's cassette culture is another instance that sheds light on the place of the alternative media in interpreting the political situation. This role can be described as that of a "media guerrilla" that wields a whole arsenal of means of justification and discourse, is recognized by the public as an alternative to the official discourse, and is often perceived as reliable. Although the era of cassettes is no more, new alternative media that represent themselves as conduits of reliable information that the establishment is trying to hide from citizens have taken their place. These media are no less subversive and are in fact even more effective; prominent among them are the Internet, Facebook, and Twitter. They often serve as both the medium and the message, staking out an alternative position to official media outlets. In this sense, the present study is something of a political parable that sheds light on the critical role of the alternative media in the contemporary post-modern political world as a means of conveying a message and, no less important, as a political message in their own right. 
Open Access This article is distributed under the terms of the Creative Commons Attribution Noncommercial License which permits any noncommercial use, distribution, and reproduction in any medium, provided the original author(s) and source are credited.

\section{References}

Abu-Lughod, L. 1989. Bedouins, cassettes and technologies of public culture. Middle East Report 159: $7-11$.

Alush, Z., and Y. Elituv. 2004. Ben porat yossef: hayav, mishnato, u-mahalakhav ha-politiyim shel ha-rav ovadia yossef (Rabbi Ovadia Yosseph). Or Yehuda: Kinneret.

Amran, M. 2006. Emtsa'ei tikshoret be-sherut ha-hevra ha-haredit: mekomam shel kalatot ha-odio veemtsa'im nosafim ke-simanei retsef u-temura ba-hevra ha-haredit (The media in the service of ultraorthodox community: the use of audiotapes and other media as indicators of continuity and change in the ultra-orthodox community). Ph.D. diss., Hebrew University of Jerusalem.

Arush, S. 2006/2007. The garden of emuna (trans: Lazer Brody). Jerusalem.

Bilsky, L. 2001. Ani ma'ashim: deri, mishpat politi ve-zikaron kolektivi (J'accuse: Deri, a political trial, and collective memory). In Shas: etgar ha-yisre'eliut, ed. Y. Peled, 279-320. Tel-Aviv: Yedioth Hachronot.

Blondheim, M., and K. Caplan. 1993. Rish'ut ha-shiddur: tikshoret ve-kalatot ba-hevra ha-haredit (On communication and audio cassettes in haredi society). Kesher 14: 51-63.

Caplan, K. 2007. Be-sod ha-siah ha-haredi (Internal popular discourse in Israeli haredi society). Jerusalem: Zalman Shazar Center.

Caplan, K. 2008. Studying haredi Mizrachim in Israel: Trends, achievements, and challenges. Studies in Contemporary Jewry 22: 169-192.

Cohen, A. 2001. Shas veha-shesa ha-dati-hiloni (Shas and the religious-secular schism). In Shas: etgar ha-yisre'eliut (Shas: the challenge of Israeliness), ed. Y. Peled, 75-101. Tel Aviv: Yedioth Ahronoth.

Dayan, A. 1999. Ha-ma'ayan ha-mitgaber: sippurah shel tenuat Shas (The story of Shas). Jerusalem: Keter.

Deshen, S. 2005. The emergence of the Israeli Sephardi ultra-orthodox movement. Jewish Social Studies 11 (2): 77-101.

El-Or, T. 2006. Mekomot shemurim: migdar ve-etniut bi-mehozot ha-dat veha-teshuva (Reserved seats: religion, gender and ethnicity in contemporary Israel). Tel Aviv: Am Oved.

Feldman, A. 2001. Gormim bi-tsemihat miflaga hadasha: hitahdut ha-sefaradim shomrei ha-tora (tenu'at shas) (Shass Party: a review of factors contributing to its evolvement). Ph.D. diss., Bar-Ilan University.

Fischer, S., and Z. Bekerman. 2001. Knesiya o kat? (Church or sect?). In Shas: etgar ha-yisre'eliut, ed. Y. Peled, 321-342. Tel-Aviv: Yedioth Hachronot.

Furman, U. 1997. Perat ve-hevra be-mahshevet ne'emanei ha-islam benei zemanenu (The individual and society in the thinking of Islamic loyalists today). In Islam ve-demokratya ba-olam ha-aravi (Islam and democracy in the Arab world), ed. M. Litvak, 44-71. Tel Aviv: Hakibbutz Hameuchad.

Givon, R. 2003. "Yesh she'at ratson gedola akhshav ba-shamayim... tizkeru—she'at ratson gedola": kenasei hahazara bi-teshuva shel ha-rav amnon yitzhak-hebetim retoriyim ve-tiksiyim ("This is a highly propitious time in the heavens... remember-a highly propitious time": Rabbi Amnon Yitzhak's teshuva rallies-rhetorical and ritual aspects). Master's thesis, Hebrew University of Jerusalem.

Goodman, Y. 2002. Ha-hazara bi-teshuva ve-zehuyuot datiyot hadashot be-yisrael bi-tehilat shenot haalpayim (The return to Jewish observance and new religious identities in Israel in the early twentyfirst century). Tel Aviv: Pinhas Sapir Center for Development, Tel Aviv University.

Goodman, Y., and Y. Bilu. 2004. "Ba-hamesh ha-dakot ha-ele she-mitpalelim-menavtim et ha-til": harada, harediut ve-yisre'eliut bi-derashot rabbanim al milhemet ha-mifrats ("In the five minutes when you pray, you maneuver the missile": fear, haredism, and Israeliness in rabbis' sermons about the Gulf War). In Ma'arbolet ha-zehuyot: diyun bikorti be-datiut uve-hiloniut be-yisrael (Maelstrom of identities: a critical look at religion and secularity in Israel), ed. Y. Yonah and Y. Goodman, 165-215. Jerusalem: Hakibbutz Hameuchad and Van Leer Institute. 
Harding, S.F. 2000. The book of Jerry Falwell: Fundamentalist language and politics. Princeton: Princeton University Press.

Hazan, H. 2000. "I Accuse". Te'oria u-vikoret (Theory and criticism) 16: 269-289.

Hirschkind, C. 2006. The ethical sounsdscape: Cassette sermons and Islamic counterpublics. New York: Columbia University Press.

Ilan, S. 2001. Haredim Baam (Haredim LTD). Jerusalem: Keter.

Kramer, M. 1997. The oracle of Hizbullah: Sayyid Muhammad Husayn Fadlallah. In Spokesmen for the despised: Fundamentalist leaders of the Middle East, ed. R.S. Appleby, 83-181. Chicago: University of Chicago Press.

Lehmann, D., and B. Siebzehner. 2006. Remaking Israeli Judaism: The challenge of Shas. London: Hurst.

Leon, N. 2003. Kenes ha-teshuva ha-hamoni ba-harediut ha-mizrahit (The mass teshuva rally in Mizrahi haredism). In Haredim yisre'elim: hishtalvut be-lo temi'a? (Israeli haredim: integration without assimilation?), ed. E. Sivan and K. Caplan, 82-98. Jerusalem: Van Leer Institute.

Leon, N. 2008. Zikui Harabim: Ovadia Yosef's approach toward religious activism and his place in the haredi movement within Mizrachi Jewry. Studies in Contemporary Jewry 22: 150-168.

Limor, Y., and C. Naveh. 2007. Ha-radyo ha-pirati be-yisrael (Pirate radio in Israel). Haifa: Pardes.

Manuel, P. 1993. Cassette culture: Popular music and technology in North India. Chicago: University of Chicago Press.

McLuhan, M. 1964. Understanding media. London: Routledge \& Kegan Paul.

Miller, F. 2007. The moral resonance of Arab media: Audiocassette poetry and culture in Yemen. Harvard Middle Eastern Monographe Series 38. Cambridge, MA: Harvard University Press.

Nir, Y. 1999. Aryeh deri: ha-aliya, ha-mashber, ha-ke'ev (Aryeh Deri: the rise, the crisis, the pain). Tel Aviv: Yedioth Ahronoth.

Peled, Y., ed. 2001. Shas: etgar ha-yisre'eliut (Shas: the challenge of Israeliness). Tel Aviv: Yedioth Ahronoth.

Perlson, I. 2006. Simha gedola ha-laila: muzika yehudit-aravit ve-zehut mizrahit (Great joy tonight: ArabJewish music and Mizrahi identity). Tel Aviv: Resling.

Picard, A. 2007. Ha-behira be-shas: ha-teshuva ha-ratsionalit li-metsuka emotsionalit (Voting for Shas: a rational response to emotional distress). Tarbut demokratit (Democratic Culture) 11: 151-201.

Regev, M. 1996. Musica mizrakhit, israeli rock and national culture in Israel. Popular Music 15: 275-284.

Sharabi, A. 2004. Sotsio-drama bi-tenu'at ha-teshuva: hakira etnografit al odot ha-kenasim shel ha-rav amnon yitzhak (Sociodrama in the teshuva movement: an ethnographic study of the rallies of Rabbi Amnon Yitzhak). Master's thesis, Bar-Ilan University.

Sivan, E. 2005. Hitnagshut be-tokh ha-islam (Clash within Islam). Tel Aviv: Am Oved.

Sreberny-Mohammadi, A. 1990. Small media for a big revolution. International Journal of Politics, Culture and Society 3: 341-371.

Tesler, R. 2003. Be-shem Hashem: Shas veha-mahapekha ha-datit (In the name of God). Jerusalem: Keter.

Warner, M. 2002. Publics and counterpublics. Public Culture 14(1): 49-90.

Yadger, Y. 2003. A disintegrating ritual: The reading of the Deri verdict as a media event of degradation. Critical Studies in Media Communication 20(2): 204-223.

Yagen, N. 2008. Netivei or (paths of light). Jerusalem: Nivei Haketav Institute.

Yuchtman-Yaar, E., and T. Hermann. 2000. Shas: The Haredi-Dovish image in changing reality. Israel Studies 5(2): 32-77.

\section{Author Biography}

Nissim Leon (Ph.D.) teaches in the Department of Sociology and Anthropology at Bar-Ilan University. He specializes in religious society in Israel, with emphasis on Orthodox groups and ethnic and class relations. 